\title{
Degradation of Methyl Violet over Fenton-Like Hydroxyapatite Catalysts, Kinetics and Thermodynamics Studies
}

\section{Yasmina Roumila ( $\square$ yas.roumila@gmail.com )}

University of Sciences and Technology Houari Boumediene: Universite des Sciences et de la Technologie Houari Boumediene

\section{Djaafar Meziani}

University of Sciences and Technology Houari Boumediene: Universite des Sciences et de la Technologie Houari Boumediene

\section{Saadia Debaghi}

University of Sciences and Technology Houari Boumediene: Universite des Sciences et de la Technologie Houari Boumediene

\section{Kaïssa Abdmeziem}

University of Sciences and Technology Houari Boumediene: Universite des Sciences et de la Technologie Houari Boumediene

\section{Research Article}

Keywords: Hydroxyapatite, Fenton like, Environment, Dye pollutant, Kinetic, Thermodynamic

Posted Date: August 13th, 2021

DOl: https://doi.org/10.21203/rs.3.rs-569149/v1

License: (c) (i) This work is licensed under a Creative Commons Attribution 4.0 International License. Read Full License 


\section{Abstract}

\title{
Degradation of Methyl Violet over Fenton-Like Hydroxyapatite Catalysts,
} Kinetics and Thermodynamics Studies

\author{
Yasmina Roumila $^{1 *}$, Djaafar Meziani ${ }^{1}$, Saadia Debaghi ${ }^{1}$, Kaïssa Abdmeziem $^{1}$ \\ ${ }^{1}$ USTHB, Faculty of Chemistry, Laboratory of Electrochemistry-Corrosion, Metallurgy and \\ Inorganic Chemistry, BP 32 El-Alia, 16111 Algiers, Algeria
}

Hydroxyapatite (HA), a calcium hydroxyphosphate was prepared via precipitation method and used as a catalyst in a Fenton like process for methyl violet (MV) dye degradation. This study is aimed to evaluate the effect of hydrogen peroxide concentration, HA dose, initial $\mathrm{pH}$, temperature and MV concentration on the catalyst performance to find out the optimum conditions leading to maximum efficiency of the Fenton process. The results showed that MV dye with a concentration of $20 \mathrm{mg} \mathrm{L}^{-1}$ can be removed within just 10 minutes at the optimal conditions of $36 \mathrm{mmol} \mathrm{L}^{-1} \mathrm{H}_{2} \mathrm{O}_{2}$ and $2.5 \mathrm{~g} \mathrm{~L}^{-1} \mathrm{HA}$ at $\mathrm{pH}$ of 6.65 and $T=48{ }^{\circ} \mathrm{C}$ ). The experimental outcome of this study also demonstrates that HA displayed a good recyclability over three cycles; while the use of scavenger highlighted that the hydroxyl radical $\mathrm{HO}^{\circ}$ was the main active species for MV degradation. The catalytic tests result of MV dye degradation were analyzed by the first-order, second-order and Benhnajady-Modirshahla-Ghanbery (BMG) kinetic models, those showing that the Fenton like reaction follows the first-order and BMG models. The activation energy of the reaction and the values of thermodynamic parameters such as standard enthalpy $\left(\Delta H^{* 0}\right)$, entropy $\left(\Delta S^{* 0}\right)$ and Gibbs free energy $\left(\Delta G^{* 0}\right)$ were also evaluated. Those results revealed that the degradation of MV over the as-synthesized material is an endothermic and non-spontaneous process.

Keywords : Hydroxyapatite ; Fenton like ; Environment ; Dye pollutant ; Kinetic ; Thermodynamic

\footnotetext{
${ }^{*}$ To whom correspondence should be addressed:

E-mail yas.roumila@gmail.com,yroumila@usthb.dz 
Water pollution becomes a universal disaster that leads to environmental degradation and declining water quality. The textile industry is an example of the industrial sector where high quantities of water are used in the dyeing process (Lellis et al. 2019). Textile industries produce a lot of wastewater, which contains a number of contaminants, among them various dyes (Wu et al. 2008). Indeed, many dyes are often resistant to biodegradation, hazardous and may even be detrimental at very low concentrations. They affect aquatic life by causing disorders and serious threats to public health (Khan et al. 2014). This is the reason why many researchers in the field of water treatment are interested in the elimination of dye pollutant by adapting several methods such as: coagulation, adsorption, biodegradation, precipitation, membrane separation and advanced oxidation processes (AOPs) (Meziani et al. 2016; Ikhsan et al. 2020; Berkessa et al. 2020; Bilińska et al. 2020; He et al. 2020; Kiani et al. 2020; Mortadi et al. 2020). In recent years, advanced oxidation processes have been studied as a promising kind of treatment method for organic wastewater, based on in situ generation of highly oxidant species, such as hydroxyl radicals $\left(\mathrm{HO}^{\circ}, E_{0}=2.81 \mathrm{~V} / \mathrm{NHE}\right)$ among others (Zaviska et al. 2009). These oxidant species are able to degrade organic pollutants up to complete mineralization. The versatility of AOPs is enhanced by the fact that they offer different possible ways for radical's production, thus allowing a better conformity with the specific treatment's requirements.

One of the most frequently used AOPs is the Fenton process, where hydroxyl radical was produced through the reduction of hydrogen peroxide $\left(\mathrm{H}_{2} \mathrm{O}_{2}\right)$ by $\mathrm{Fe}^{2+}$. Fenton's reagent is an interesting solution since it allows high depuration levels at room temperature and pressure conditions, using innocuous and easy to handle reactants (Babuponnusami and Muthukumar 2014; Wang et al. 2016). Likewise, the use of iron as a catalyst has major advantages such as: high abundance, environmental compatibility, low toxicity and high reactivity. However, Fenton processes present some limitations such as the requirement of strict $\mathrm{pH}$ control $(3<\mathrm{pH}$ $<4$ ), and difficulties in the recycling of the homogeneous catalyst leading to high operating cost (Ajoudanian and Nezamzadeh-Ejhieh 2015; Bello et al. 2019). In order to overcome these disadvantages, iron was either complexed with organic molecules, impregnated in different solid catalysts (zeolites, porous carbon and clays)(Gonzalez-Olmos et al. 2011; Hassan and Hameed 2011; Fida et al. 2017; Lan et al. 2020; Long et al. 2020; Zárate-Guzmán et al. 2020; Zhang et al. 2020), or used in oxide form such as goethite $(\mathrm{FeOOH})$, magnetite $\left(\mathrm{Fe}_{3} \mathrm{O}_{4}\right)$ and hematite $\left(\mathrm{Fe}_{2} \mathrm{O}_{3}\right)$ (Hassan and Hameed 2011; Sebatini et al. 2020; Bilińska et al. 2020; Tang et 
al. 2020). Furthermore, materials based on other transition metals were used as heterogeneous Fenton-like catalysts such as metal oxides, metalphosphates and MOFs (Roumila et al. 2016; Zhou et al. 2020; Dong et al. 2021).

Among these types of materials, our attention was focused on metalphosphates. These materials have variable properties, due to their structures, textures and the presence of metals that are considered as active sites involved in catalytic reactions. HA with chemical formula of $\mathrm{Ca}_{5}\left(\mathrm{PO}_{4}\right)_{3} \mathrm{OH}$ is a well-known material in metalphosphates family, synthesized in various forms such as powders, micro/nano-crystals, dense or porous blocks/sheets/ceramics. HA is the most stable phase among various calcium phosphates under neutral or basic conditions and it is well known for its bioactivity, biocompatibility, lack of toxicity and excellent surface ionexchange properties (Venkateswarlu et al. 2010; Fihri et al. 2017). HA is thus used in various fields, it has displayed promising potential in biomedical fields due to its chemical compositional and biological similarity to native tissues (Sangeetha et al. 2018; Riaz et al. 2018; Ciobanu and Harja 2019). It is also applied in other fields of industrial or technological interests such as in different organic reactions as a catalyst (Sebti et al. 2002; Saber et al. 2003; Zahouily et al. 2003), in water purification as a photocatalyst (Nishikawa 2004; Fihri et al. 2017), or as adsorbent for heavy metals like lead and cadmium (Oliva et al. 2011; Oulguidoum et al. 2019; Vahdat et al. 2019) and organic contaminants (Harja and Ciobanu 2018; Ooi et al. 2019).

In this work, we report the synthesis and the characterization of HA obtained by using the precipitation method. The catalytic performances of our material were further investigated in MV dye elimination using heterogeneous Fenton-like process. The effects of various conditions that may influence the catalytic reaction, including hydrogen peroxide concentration, HA dose, dye concentrations, temperature and initial $\mathrm{pH}$ of the solution were investigated. The kinetic and thermodynamic studies of MV dye degradation, were also established.

\section{MATERIALS AND METHODS}

\subsection{Preparation of Catalyst}

HA material studied in this work was synthesized by precipitation method using a stoichiometric ratio of 1.67. Initially, two aqueous solutions containing $0.3 \mathrm{~mol} \mathrm{~L}^{-1}$ of $\left(\mathrm{NH}_{4}\right)_{2} \mathrm{HPO}_{4}$ and $0.5 \mathrm{~mol} \mathrm{~L}^{-1}$ of $\mathrm{Ca}\left(\mathrm{NO}_{3}\right)_{2}, 4 \mathrm{H}_{2} \mathrm{O}$ were prepared and their $\mathrm{pH}$ were adjusted to 11 using ammonia $24 \%$. The $\left(\mathrm{NH}_{4}\right)_{2} \mathrm{HPO}_{4}$ solution was drop-wisely added to the $\mathrm{Ca}\left(\mathrm{NO}_{3}\right)_{2}, 4 \mathrm{H}_{2} \mathrm{O}$ solution under vigorous stirring, while maintaining the $\mathrm{pH}$ at 11 using 
ammonia. The mixture was then left under stirring at room temperature for 24 hours and the obtained precipitate was washed several times with distilled water. After drying at $100{ }^{\circ} \mathrm{C}$ overnight, the white precipitate was calcined for two hours at 120,600 and $900{ }^{\circ} \mathrm{C}$.

\subsection{Characterization}

X-ray powder diffraction (XRD) patterns were recorded on a Mini Diffractometer MD10 equipped with $\mathrm{Cu} \mathrm{K} \alpha$ radiation $(\lambda=1.5406 \AA)$. Scanning electron microscopy image was performed on a JEOL JSM- 6360 LV emission scanning electron microscope (SEM) operating at $5.0 \mathrm{kV}$. The Fourier-transform infrared (FTIR) spectra were obtained using KBr technique on a JASCO-4100 FTIR spectrometer in the range of 400 to $4000 \mathrm{~cm}^{-1}$.

\subsection{Fenton-like catalytic reaction}

The Fenton-like catalytic tests were carried out by adding a desired dose of HA material to $10 \mathrm{ml}$ of $\mathrm{MV}$ dye solution with a chosen concentration. In order to determine the optimal conditions of the catalytic reaction, the effect of different parameters was investigated. The suspension was kept under stirring for 30 minutes to achieve adsorption/desorption equilibrium and then different doses of $\mathrm{H}_{2} \mathrm{O}_{2}$ were added into the reaction system. The optimal dose of $\mathrm{H}_{2} \mathrm{O}_{2}$ was then taken for all other catalytic tests. The $\mathrm{pH}$ of solution was adjusted to a desired value using $0.1 \mathrm{M} \mathrm{H}_{2} \mathrm{SO}_{4}$ or $0.5 \mathrm{M} \mathrm{KOH}$ aqueous solutions, and monitored online using a $\mathrm{pH}$ meter. The effect of temperature on the catalytic reaction was carried out in a cylindrical Pyrex double-walled reactor equipped with a thermostat. To identify the radical species responsible for the degradation of MV dye, tert-butanol (TBT) was added at different doses in the reaction solution as a scavenger. To determine the degradation efficiency, $3 \mathrm{~mL}$ of the suspension was collected and centrifuged at regular time intervals to separate the catalyst particles. Afterward, the obtained solution was analyzed by using a double-beam spectrophotometer (Jasco V-650) at maximum absorption wavelength of MV dye $\left(\lambda_{\max }=582 \mathrm{~nm}\right)$. The degradation efficiency was calculated using the relation $A_{t} / A_{0}$, where $A_{\mathrm{t}}$ and $A_{0}$ are the maximum absorbance at time $\mathrm{t}$ and zero respectively.

\section{RESULTS AND DISCUSSION}

\subsection{Catalyst Characterization}

The X-ray diffractogram of the as synthetized material (Fig. 1-a) shows the reflection peaks of a pure hydroxyapatite crystallizing in the hexagonal system under space group $\mathrm{P}_{3} / \mathrm{m}$, with $a=b=9.41898 \AA ; c=6.88119 \AA$ and $\alpha=\beta=90^{\circ} ; \gamma=120^{\circ}$ as cell parameters according 
to JCPDS card $n^{\circ}$. 9-432. To study the effect of the synthesis temperature, the HA material was characterized by X-ray diffraction after each heat treatment at 120, 600 and $900{ }^{\circ} \mathrm{C}$ (Fig. 1-b) and the corresponding diffractograms confirm the presence of the apatitic structure with broad peaks for the material heated at $120{ }^{\circ} \mathrm{C}$. With increasing temperature up to $600{ }^{\circ} \mathrm{C}$, no change in diffraction peaks was observed. However, further increase to $900{ }^{\circ} \mathrm{C}$ revealed narrow peaks with a better resolution, likely due to improved crystallization. These results are in good agreement with other studies which show that an increase in the calcination temperature can control the grains morphology of hydroxyapatite and leads to well crystallized structures (Bensalah et al. 2018).

Fig. 1 Diffractogram of: (a) synthesized hydroxyapatite; (b) hydroxyapatite at different calcination temperatures

Recent studies have shown the existence of many morphologies for hydroxyapatites among them: cubic rods (Raghav et al. 2018), needle shape (Bensalah et al. 2018), agglomerated particles (Jastrzębski et al. 2011), microspheres (Yang et al. 2014) and others. These morphologies occur as a consequence of the elaboration method or following the variation of different parameters during the synthesis. For this purpose, we undertook to characterize the as-synthetized HA by the SEM technique. The micrography illustrated in Fig. 2 shows many agglomerates with mixed morphology. These agglomerates are composed from fine crystals whose sizes are less than $1 \mu \mathrm{m}$ and other crystals in the form of platelets whose sizes are varying from 1 to $5 \mu \mathrm{m}$.

Fig. 2 SEM image of synthesized HA

The FTIR spectrum (Fig. 3) showed absorption bands at $1050 \mathrm{~cm}^{-1}$ attributed to the asymmetric stretching vibrations of the P-O bonds, while the peaks at 603 and $571 \mathrm{~cm}^{-1}$ are due to bending vibrations of O-P-O in phosphates groups (Roumila et al. 2018; Krukowski et al. 2018). The two peaks at $3670 \mathrm{~cm}^{-1}$ and $630 \mathrm{~cm}^{-1}$ are attributed to the $\mathrm{OH}$ groups of hydroxyapatite (Berzina-Cimdina and Borodajenko 2012). The spectrum shows a wide band around $3500 \mathrm{~cm}^{-1}$ and a peak at $1636 \mathrm{~cm}^{-1}$ corresponding respectively to the elongation and deformation vibrations of the $\mathrm{O}-\mathrm{H}$ bonds in adsorbed water molecules (Wang et al. 2018).

Fig. 3 FTIR spectrum of $\mathrm{Ca}_{5}\left(\mathrm{PO}_{4}\right)_{3} \mathrm{OH}$

\subsection{Elimination of MV in different systems}

The elimination of MV dye in various systems, namely, $\mathrm{HA}, \mathrm{H}_{2} \mathrm{O}_{2}$, and $\mathrm{HA}+\mathrm{H}_{2} \mathrm{O}_{2}$, was compared to study the catalytic activity of HA material in the HA/Fenton-like process. MV dye 
degradation efficiency versus reaction time was shown in Fig. 4a. As it can be seen, about 20 $\%$ of MV dye was removed from the solution after 380 min either by oxidation with $\mathrm{H}_{2} \mathrm{O}_{2}$ system or by adsorption on HA material. These results indicated that the removal efficiency provided by both systems is too low to meet the practical needs of MV elimination. However, for the $\mathrm{HA}+\mathrm{H}_{2} \mathrm{O}_{2}$ system, all of the MV dye was removed after $210 \mathrm{~min}$, which indicates that the HA-catalyzed heterogeneous Fenton-like system was the main process for the elimination of MV pollutant. This result is well demonstrated by the absorption spectra of MV dye remaining in solution, that were recorded every $30 \mathrm{~min}$ (Fig. 4b). Indeed, these spectra show a decay of the main absorption band of MV dye, over time.

Fig. 4 (a) Comparison of the degradation efficiency of MV at $20 \mathrm{mg} \mathrm{L}^{-1}$ under various systems; (b) Absorption spectra of MV according to the Fenton-like process $\left(T=19 \pm 2{ }^{\circ} \mathrm{C}\right.$, $\mathrm{pH}=6.65,[\mathrm{MV}]=20 \mathrm{mg} \mathrm{L}^{-1}, \mathrm{HA}$ dose $=2.5 \mathrm{~g} \mathrm{~L}^{-1}$ and $\left.\left[\mathrm{H}_{2} \mathrm{O}_{2}\right]=12 \mathrm{mmol} \mathrm{L}^{-1}\right)$

\subsection{Reaction mechanism}

Despite its obvious importance, the mechanism of the Fenton or Fenton-like process reaction is not fully understood. The decomposition of hydrogen peroxide in our case could occur on the calcium sites present in the surface of catalyst according to the following equation:

$\equiv \mathrm{Ca}^{\mathrm{II}}$ sites $+\mathrm{H}_{2} \mathrm{O}_{2} \rightarrow \equiv \mathrm{Ca}^{\mathrm{II}}$ sites $\mathrm{H}_{2} \mathrm{O}_{2}$

$\equiv \mathrm{Ca}^{\mathrm{II}}$ sites $\mathrm{H}_{2} \mathrm{O}_{2} \rightarrow \equiv \mathrm{Ca}^{\mathrm{I}}$ sites $+\mathrm{HO}_{2}{ }^{\cdot}+\mathrm{H}^{+}$

$\equiv \mathrm{Ca}^{\mathrm{II}}$ sites $+\mathrm{HO}_{2}{ }^{\cdot} \rightarrow \equiv \mathrm{Ca}^{\mathrm{I}}$ sites $+\mathrm{O}_{2}+\mathrm{H}^{+}$

$\equiv \mathrm{Ca}^{\mathrm{I}}$ sites $+\mathrm{H}_{2} \mathrm{O}_{2} \rightarrow \equiv \mathrm{Ca}^{\mathrm{II}}$ sites $+\mathrm{HO}^{\bullet}+\mathrm{OH}^{-}$

To identify the main active species and to have a better understanding of the reaction pathway during the Fenton-like process, TBT is used as an efficient $\mathrm{HO}^{\bullet}$ scavenger according to reaction (5) (Duesterberg and Waite 2006; Ding et al. 2016) :

$$
\mathrm{C}\left(\mathrm{CH}_{3}\right)_{3} \mathrm{OH}+\mathrm{HO}^{\cdot} \longrightarrow \mathrm{C}\left(\mathrm{CH}_{3}\right)_{3} \mathrm{O}^{\cdot}+\mathrm{H}_{2} \mathrm{O}
$$

As demonstrated in Fig. 5, the efficiency degradation of MV is greatly influenced by the presence of the scavenger, where the efficiency decreases with increasing TBT concentration. The degraded MV amount in the presence of $0.27 ; 2$ and $3 \mathrm{~mol} \mathrm{~L}^{-1}$ of the scavenger was found to be $68 ; 38$ and $10 \%$ respectively after $210 \mathrm{~min}$, while the absence of the scavenger in the solution gives rise to a total elimination of MV. These results indicate that $\mathrm{HO}^{\bullet}$ radicals are the main active species involved in the MV degradation process. Similar results are reported in the literature (Wan et al. 2017). 
Fig. 5 Degradation of MV in the presence of TBT at different concentrations ( $T=19$ $\pm 2{ }^{\circ} \mathrm{C}, \mathrm{pH}=6.65,[\mathrm{MV}]=20 \mathrm{mg} \mathrm{L}^{-1}, \mathrm{HA}$ dose $\left.=2.5 \mathrm{~g} \mathrm{~L}^{-1},\left[\mathrm{H}_{2} \mathrm{O}_{2}\right]=12 \mathrm{mmol} \mathrm{L}^{-1}\right)$

\subsection{Effect of the experimental parameters on the heterogeneous Fenton like process}

The Fenton-like catalytic degradation of organic pollutants over HA particles is influenced by many reaction parameters such as $\mathrm{H}_{2} \mathrm{O}_{2}$ concentration, catalyst load, temperature and solution $\mathrm{pH}$.

\subsubsection{Effect of $\mathrm{H}_{2} \mathrm{O}_{2}$ concentration}

The concentration of $\mathrm{H}_{2} \mathrm{O}_{2}$, source of $\mathrm{HO}^{\bullet}$ radicals, can influence the Fenton-like process. Therefore, this parameter has been studied. The following curves (Fig. 6.) show remaining MV amount in solution as a function of time at different $\mathrm{H}_{2} \mathrm{O}_{2}$ concentrations.

Fig. 6 Effect of $\mathrm{H}_{2} \mathrm{O}_{2}$ concentration on MV dye degradation.

$$
\left(T=19 \pm 2{ }^{\circ} \mathrm{C}, \mathrm{pH}=6.65,[\mathrm{MV}]=20 \mathrm{mg} \mathrm{L}^{-1}, \mathrm{HA} \text { dose }=2.5 \mathrm{~g} \mathrm{~L}^{-1}\right) .
$$

For each dose of $\mathrm{H}_{2} \mathrm{O}_{2}$ used, the amount of $\mathrm{MV}$ remaining in solution decreases gradually over time. When $\mathrm{H}_{2} \mathrm{O}_{2}$ concentration increases from 9 to $36 \mathrm{mmol} \mathrm{L}^{-1}$ the elimination rate increases. This result suggests that more $\mathrm{HO}^{\bullet}$ radicals are formed which increased the MV dye degradation rate. However, when the $\mathrm{H}_{2} \mathrm{O}_{2}$ concentration is higher than $36 \mathrm{mmol} \mathrm{L}^{-1}$, the degradation efficiency decreases. For example, at $300 \mathrm{mmol} \mathrm{L}^{-1}$ of $\mathrm{H}_{2} \mathrm{O}_{2}$, the degradation efficiency drops to $77 \%$. This decrease in the elimination rate is probably due to the consumption of the hydroxyl radicals $\mathrm{HO}^{*}$ by the excess of hydrogen peroxide according to the reaction (6), producing other radicals such as $\mathrm{O}_{2}^{-}$and $\mathrm{HO}_{2}^{-}$, which have a lower oxidation capacity (Wang et al. 2014; Sun et al. 2018).

$$
\mathrm{H}_{2} \mathrm{O}_{2}+\mathrm{HO}^{\bullet} \longrightarrow \mathrm{HO}_{2}^{\circ}
$$

This study indicated that the optimal dosage of $\mathrm{H}_{2} \mathrm{O}_{2}$ is $36 \mathrm{mmol} \mathrm{L} \mathrm{L}^{-1}$. Therefore, this latter concentration was chosen for the remainder of the study.

\subsubsection{Effect of the Initial pH}

$\mathrm{pH}$ is one of the most important factors influencing the Fenton or Fenton-like process. In general, the activity of heterogeneous Fenton catalysts is very limited at neutral and alkaline $\mathrm{pH}$. To better study this effect, three $\mathrm{pH}$ values including the original one $(\mathrm{pH}=6.65)$ were tested to degrade MV dye from solution, with an initial concentration of $20 \mathrm{mg} \mathrm{L}^{-1}$ and at a temperature of $19 \pm 2{ }^{\circ} \mathrm{C}$.

The curves illustrated in Fig. 7 show a progressive decrease in dye amount remaining in solution for each $\mathrm{pH}$ value. The results indicate that a total removal of MV dye from solution 
was reached after $120 \mathrm{~min}$ at $\mathrm{pH} 6.65$ against $150 \mathrm{~min}$ at $\mathrm{pH} 9.45$. The slight drop in degradation efficiency observed at $\mathrm{pH}=9.45$ can be explained by the low oxidation potential of the hydroxyl radicals in basic medium (Ji et al. 2011). As for $\mathrm{pH}$ value around 5, a weak catalytic performance was observed probably due to the reactivity of the excess $\mathrm{H}^{+}$protons with the $\mathrm{HO}^{*}$ radicals, to form water molecules according to the reaction (7) (Wan et al. 2017). This is consistent with the increase in the $\mathrm{pH}$ value of the solution from 5 to 6.75 at the end of the catalytic reaction.

$$
\mathrm{HO}^{\bullet}+\mathrm{H}^{+}+e^{-} \longrightarrow \mathrm{H}_{2} \mathrm{O}
$$

The experimental data indicated that the best degradation efficiency can be obtained at an optimized initial $\mathrm{pH}$ of 6.65 .

Fig. 7 Effect of initial $\mathrm{pH}$ on MV degradation

$$
\left(T=19 \pm 2{ }^{\circ} \mathrm{C},[\mathrm{MV}]=20 \mathrm{mg} \mathrm{L}^{-1},\left[\mathrm{H}_{2} \mathrm{O}_{2}\right]=36 \mathrm{mmol} \mathrm{L}^{-1}, \mathrm{HA} \text { dose }=2.5 \mathrm{~g} \mathrm{~L}^{-1}\right)
$$

\subsubsection{Effect of Catalyst dose}

We have already reported before that in the absence of HA catalyst, the degradation efficiency of MV is negligible (only $13 \%$ after $210 \mathrm{~min}$ ) (see section 3.2.1), highlighting the vital role of the HA catalyst in the Fenton-like process. To get inside this effect, several tests with different catalyst doses were carried out. The curves show that by increasing the catalyst dose from 0.75 to $2.5 \mathrm{~g} \mathrm{~L}^{-1}$, a significant increase in the degradation efficiency is observed (Fig. 8). Indeed, when the HA dose goes from 0.75 to $2 \mathrm{~g} \mathrm{~L}^{-1}$, the degradation efficiency increases from 21 to $50 \%$ after $30 \mathrm{~min}$. By increasing HA dosage to $2.5 \mathrm{~g} \mathrm{~L}^{-1}$, a significant removal is achieved (82.7\%) after $30 \mathrm{~min}$ and a total discoloration was obtained after $120 \mathrm{~min}$. These results can be explained by the increase in the active sites due to the increase in the catalyst dose, which leads to a greater generation of $\mathrm{HO}^{\bullet}$ radicals improving the degradation rate. Thus, $2.5 \mathrm{~g} \mathrm{~L}^{-1} \mathrm{HA}$ is suitable for the reaction system.

Fig. 8 Effect of the catalyst dose on the degradation efficiency of MV $\left(T=19 \pm 2{ }^{\circ} \mathrm{C}\right.$,

$$
\left.\mathrm{pH}=6.65,[\mathrm{MV}]=20 \mathrm{mg} \mathrm{L}^{-1} \text { and }\left[\mathrm{H}_{2} \mathrm{O}_{2}\right]=36 \mathrm{mmol} \mathrm{L}^{-1}\right)
$$

\subsubsection{Effect of the reaction Temperature}

The effect of reaction temperature on the MV solution discoloration was also studied. From Fig. 9 it can be seen that the degradation efficiency increased with the increase in reaction temperature. Indeed, MV dye is removed from the solution after $120 \mathrm{~min}$ at temperatures of 19 and $28{ }^{\circ} \mathrm{C}$, after $60 \mathrm{~min}$ at $36{ }^{\circ} \mathrm{C}$ and after just $10 \mathrm{~min}$ at $48{ }^{\circ} \mathrm{C}$ In fact, a higher temperature increases the rate of reaction between the hydrogen peroxide and the catalyst, thus increasing 
the rate of generation of the oxidizing species. In addition, a higher temperature can provide more energy to the system in the aim to overcome the reaction activation energy (Wang et al. 2014).

Fig. 9 Effect of temperature on MV degradation $\left(\mathrm{pH}=6.65,[\mathrm{MV}]=20 \mathrm{mg} \mathrm{L}^{-1}\right.$,

$$
\left[\mathrm{H}_{2} \mathrm{O}_{2}\right]=36 \mathrm{mmol} \mathrm{L}^{-1}, \mathrm{HA} \text { dose }=2.5 \mathrm{~g} \mathrm{~L}^{-1} \text { ) }
$$

\subsubsection{Effect of the initial concentration of the MV solution}

The degradation efficiency by the Fenton-like method on HA catalyst was studied at different concentrations of MV and the results are shown in Fig. 10.

Fig. 10 Effect of the initial concentration of MV solutions

$$
\left(T=19 \pm 2{ }^{\circ} \mathrm{C}, \mathrm{pH}=6.65,\left[\mathrm{H}_{2} \mathrm{O}_{2}\right]=36 \mathrm{mmol} \mathrm{L}^{-1} \text { and } \mathrm{HA} \text { dose }=2.5 \mathrm{~g} \mathrm{~L}^{-1}\right)
$$

Overall, it can be seen that as the initial MV concentration increases, the degradation efficiency decreases and the time required for total discoloration increases. The curves showed that all the MV dye was eliminated after $120 \mathrm{~min}$ at a concentration of $20 \mathrm{mg} \mathrm{L}^{-1}$ and $330 \mathrm{~min}$ at a concentration of $25 \mathrm{mg} \mathrm{L}^{-1}$. On the other hand, this time was not sufficient to eliminate all the MV from the solution at a concentration of $30 \mathrm{mg} \mathrm{L}^{-1}$. Similar behavior has been observed in other works on Fenton-like process (Park et al. 2018). The low degradation efficiency at high concentrations can be explained by the limited number of $\mathrm{HO}^{*}$ radicals in the reaction medium compared to the high number of MV molecules ([MV] $>\left[\mathrm{HO}^{\circ}\right]$ ). Therefore, under these experimental conditions, the percentage of generated $\mathrm{HO}^{\bullet}$ radicals is insufficient to degrade all the dye molecules (Park et al. 2018).

\subsection{Catalyst recycling tests}

In order to assess the recycling efficiency as well as stability of the HA during the MV degradation, three cycles of Fenton-like process were carried out under the optimum conditions. After each experiment, the filtrate is removed and a new fresh solution of MV dye and $\mathrm{H}_{2} \mathrm{O}_{2}$ is added onto the same catalyst sample. The results showed that until the third cycle, the degradation efficiency remained effective with the same removal percentage (Fig.11).

Fig. 11 Catalyst recycling in MV degradation via a Fenton like process $(T=19 \pm 2$

$$
{ }^{\circ} \mathrm{C}, \mathrm{pH}=6.65,[\mathrm{MV}]=20 \mathrm{mg} \mathrm{L}^{-1},\left[\mathrm{H}_{2} \mathrm{O}_{2}\right]=36 \mathrm{mmol} \mathrm{L}^{-1} \text { and } \mathrm{HA} \text { dose }=2.5 \mathrm{~g} \mathrm{~L}^{-1} \text { ) }
$$

\subsection{Kinetic studies}

In order to study the degradation kinetics of MV dye by the Fenton-like process, three typical kinetic models were applied, i.e., the first-order, the second-order and the Behnajady- 

respectively (Santana et al. 2019).

$$
\ln \frac{C_{t}}{C_{0}}=-k_{1} t
$$

$$
\frac{t}{1-\frac{C_{t}}{C_{0}}}=m+b t
$$

where, $C_{0}\left(\mathrm{mg} \mathrm{L}^{-1}\right)$ is the initial concentration of $\mathrm{MV}, C_{t}\left(\mathrm{mg} \mathrm{L}^{-1}\right)$ is the $\mathrm{MV}$ concentration at time $t(\mathrm{~min}) ; k_{1}\left(\mathrm{~min}^{-1}\right)$ is the rate constant for the first-order and $k_{2}\left(\mathrm{mg}^{-1} \mathrm{~L}\right.$ $\min ^{-1}$ ) is the rate constant for the second-order model; $m$ (min) and $b$ (dimensionless) are two characteristic constants for the BMG model that are related to reaction rates and oxidation capacity, respectively. The two parameters in BMG model are evaluated by examining time approaching zero or infinity, thus leading to the initial MV removal rate $(1 / m)$ and the theoretical maximum oxidation capacity of the catalyst $(1 / b)$. Accordingly, higher values of $1 / m$ and $1 / b$ indicate better catalytic performance. The fitted plots of the three kinetic models are shown in Supporting Information (Fig. S1, S2 and S3), while the obtained parameters are given in Table 1.

From these results, it could be seen that under the different reaction conditions, the values of the correlation factor in the first-order model and in the BMG model are closer to 1 as compared to those of the second order model. This implies that the experimental results are correctly described by the first order and BMG models. Indeed, the values of the different parameters of these models are in good agreement with experimental results as discussed below. For the influence of $\mathrm{H}_{2} \mathrm{O}_{2}$ concentration, the variation of $k_{1}$ and the two parameters $1 / \mathrm{m}$ and $1 / b$ are shown in Supplementary Fig. S4a and Fig. S4b respectively. As seen in these figures, a sharp increase in $k_{1}$ and $1 / m$ is observed when the $\mathrm{H}_{2} \mathrm{O}_{2}$ concentrations go from 9 to $36 \mathrm{mmol} \mathrm{L}^{-1}$. However, $k_{1}$ and $1 / m$ decreased when the concentration of $\mathrm{H}_{2} \mathrm{O}_{2}$ was higher than $36 \mathrm{mmol} \mathrm{L}^{-1}$. This result can be explained by the lack of radicals in solution caused by the excess of $\mathrm{H}_{2} \mathrm{O}_{2}$ as reported in section 3.2.3.1. As for the oxidation capacity (1/b), it keeps the same values with a variance of \pm 0.02 at each concentration of $\mathrm{H}_{2} \mathrm{O}_{2}$.

As it was demonstrated previously, the reaction rate is influenced by catalyst dosage. Practically, the increase in the HA dosage from $0.75 \mathrm{~g} \mathrm{~L}^{-1}$ to $2 \mathrm{~g} \mathrm{~L}^{-1}$ could increase the initial removal rate as illustrated in Supplementary Fig. S4C. Indeed, $k_{1}$ increased from 0.0037 to $0.015 \mathrm{~min}^{-1}$ and $1 / \mathrm{m}$ from 0.006 to $0.04 \mathrm{~min}^{-1}$, and further increasing of the HA dose to $2.5 \mathrm{~g}$ $\mathrm{L}^{-1}$, gives rise to the highest values of $k_{l}$ and $1 / \mathrm{m}$. In parallel, the oxidation capacity $(1 / b)$ 
remains almost constant and ranging around the value of 1 to reach a maximum value of 1.08 at $1.5 \mathrm{~g} \mathrm{~L}-1$ of HA dose and a minimum value of 0.92 at $1 \mathrm{~g} \mathrm{~L}-1$ (Supplementary Fig. S4d).

The degradation rates $\left(k_{l}\right.$ and $\left.1 / m\right)$ and the maximum degradation capacity $(1 / b)$, as a function of initial pH, are shown in Supplementary Fig. S4e and Fig. S4f. It can be seen that the oxidation capacity $(1 / b)$ slightly increased while the removal rates $\left(k_{l}\right.$ and $\left.1 / m\right)$ increase by increasing $\mathrm{pH}$ from 5 to 6.65 . However, at $\mathrm{pH}$ value over than 6.65 the removal rates decrease thus suggesting that the most favorable kinetic rate values can be obtained at an optimized initial $\mathrm{pH}$ of 6.65 .

The kinetics of MV degradation at different reaction temperatures were also studied and represented in Supplementary Fig. S4g and Fig. S4h. From these figures, an increase in the value of the two removal rates $\left(k_{l}\right.$ and $\left.1 / m\right)$ is observed when the temperature goes from 20 to $36{ }^{\circ} \mathrm{C}$, while the oxidation capacity keeps almost the same value. These results suggest that the mobility of the reactants was favored by the applied thermal energy as already discussed.

The kinetic rate is also influenced by the initial dye concentration. The curves in Supplementary Fig. $\mathrm{S} 4 \mathrm{i}$ and Fig. $\mathrm{S} 4 \mathrm{j}$ indicate that the initial removal rates $\left(k_{1}\right.$ and $\left.1 / m\right)$ decreased as increasing initial MV concentration and this is due to the increase in MV molecules compared to those of $\mathrm{HO}^{\bullet}$ radicals generated in solution $\left([\mathrm{MV}]>\left[\mathrm{HO}^{\circ}\right]\right)$. In fact, the concentration of $\mathrm{H}_{2} \mathrm{O}_{2}$ in the system was constant and equal to $36 \mathrm{mM}$ thus fixing the number of radicals generated in the solution leading to an almost constant oxidation capacity $1 / b$.

\subsection{Thermodynamic studies}

Based on the Arrhenius equation $k_{1}=A \exp \left(-\frac{E_{a}}{R T}\right)$ where $k_{l}$ is the rate constant, $A$ is a pre-exponential factor, $R$ is the universal gas constant $\left(8.314 \mathrm{~J} \mathrm{~mol}^{-1} \mathrm{~K}^{-1}\right)$ and $T$ is the temperature in $\mathrm{K}$ (Zhang et al. 2014), the activation energy $\left(E_{a}\right)$ of the reaction was evaluated by plotting $\ln k$ against 1/T (Fig. S5a in the Supporting Information). $E_{a}$ was determined to be $30.72{\mathrm{~kJ} . ~ \mathrm{~mol}^{-1}}^{-}$close to that reported by Suraj. P 2019 (Suraj et al. 2019). This value is higher than $E_{a}$ of the diffusion-controlled reaction that usually ranges within $10-13 \mathrm{~kJ} \mathrm{~mol}^{-1}$ (Zubir et al. 2014) which implies that $k_{1}$ for this heterogeneous reaction is dominated by the rate of intrinsic chemical reactions on the surface of active sites rather than the rate of mass transfer as reported elsewhere (Xue et al. 2009).

The use of the theory of activated complexes developed by Eyring in 1930 (Khosroshahi and Mehrizad 2019) allowed us to calculate the enthalpy $\left(\Delta H^{\circ *}\right)$ and the entropy $\left(\Delta S^{\circ *}\right)$ of activation. The Eyring equation also called Eyring-Polanyi is given as follows: 
where $h$ is the Plank constant $\left(6.6210^{-34} \mathrm{~J} \mathrm{~s}^{-1}\right)$ and $k_{B}$ the Boltzmann constant (1.38 .10-

$\left.{ }^{23} \mathrm{~J} \mathrm{k}^{-1}\right), \Delta H^{\circ *}$ and $\Delta S^{\circ *}$ values were determined based on the slope and intercept of the $\ln \left(k_{1}\right.$ $/ T)$ versus (1/T) (Fig. S5b in the Supporting Information). Since the values of the free activation enthalpy $\Delta G^{\circ *}$ at different temperatures were calculated using the relationship of $\Delta G^{\circ *}=\Delta H^{\circ *}$ - $T \Delta S^{\circ *}$. The results obtained are reported in the following table:

According to the obtained results, the free activation enthalpy $\Delta G^{\circ *}$ is positive, which means that the Fenton-like reaction is non-spontaneous. The positive sign of the enthalpy suggests an endothermic process, which was predictable since the reaction was favored by a rise in temperature. The negative value of the entropy reflects and enhances regularity at the catalyst/solution interface during the Fenton-like reactions.

\section{Conclusions}

HA was prepared by precipitation method and characterized by many physicochemical techniques. The compound was used as a catalyst in a heterogeneous Fenton like process for the elimination of a cationic dye. At room temperature and neutral initial $\mathrm{pH}$, a total removal was obtained within 120 min with $\mathrm{HA}$ dose of $2.5 \mathrm{~g} \mathrm{~L}^{-1}, \mathrm{H}_{2} \mathrm{O}_{2} 36 \mathrm{mmol} \mathrm{L}^{-1}$ and initial MV concentration of $20 \mathrm{mg} \mathrm{L}^{-1}$. Furthermore, at $48{ }^{\circ} \mathrm{C}$, a complete elimination was reached after just $10 \mathrm{~min}$. The use of a scavenger highlighted the important role of $\mathrm{HO}^{*}$ radicals in the process. The involved process was evaluated by both kinetic and thermodynamic studies. The results revealed that the kinetic rate follows the first-order and BMG kinetic models, where the removal rate increases by increasing $\mathrm{H}_{2} \mathrm{O}_{2}$ concentration, catalyst dosage and temperature. $\mathrm{A}$ good correlation was observed between empirical and modelled data. The thermodynamic parameters indicated a non-spontaneous and endothermic process. Based on the findings of the present research, HA catalyst would have potential applications in the field of wastewater treatment due to its non-toxicity, chemical stability, good catalytic activity and easy recycling.

Supplementary Information The online version contains supplementary material.

\section{Acknowledgments}

The authors thank MHESR (Ministry of Higher Education and Scientific Research) Algeria, for the financial support. 
Author contribution: All authors contributed to the study conception and design. Material preparation, data collection, and analysis were performed by Y. Roumila, S. Debaghi and D. Meziani. The manuscript was written by Y. Roumila and D. Meziani. K. Abdmeziem supervised all of the work and contributed to the writing and editing of the manuscript. All authors read and approved the final manuscript.

Availability of data and material Not applicable.

\section{Declarations}

Ethical approval Not applicable.

Consent to participate Not applicable.

Consent for publication Not applicable.

Competing interests The authors declare no competing interests

\section{References}

Ajoudanian N, Nezamzadeh-Ejhieh A (2015) Enhanced photocatalytic activity of nickel oxide supported on clinoptilolite nanoparticles for the photodegradation of aqueous cephalexin. Mater Sci Semicond Process 36:162-169. https://doi.org/10.1016/j.mssp.2015.03.042

Babuponnusami A, Muthukumar K (2014) A review on Fenton and improvements to the Fenton process for wastewater treatment. J Environ Chem Eng 2:557-572. https://doi.org/10.1016/j.jece.2013.10.011

Bello MM, Abdul Raman AA, Asghar A (2019) A review on approaches for addressing the limitations of Fenton oxidation for recalcitrant wastewater treatment. Process Saf Environ Prot 126:119-140. https://doi.org/10.1016/j.psep.2019.03.028

Bensalah H, Bekheet MF, Alami Younssi S, et al (2018) Hydrothermal synthesis of nanocrystalline hydroxyapatite from phosphogypsum waste. J Environ Chem Eng 6:1347-1352. https://doi.org/10.1016/j.jece.2018.01.052

Berkessa YW, Yan B, Li T, et al (2020) Treatment of anthraquinone dye textile wastewater using anaerobic dynamic membrane bioreactor: Performance and microbial dynamics. Chemosphere 238:124539. https://doi.org/10.1016/j.chemosphere.2019.124539

Berzina-Cimdina L, Borodajenko N (2012) Research of Calcium Phosphates Using Fourier 
Transform Infrared Spectroscopy. In: Infrared Spectroscopy - Materials Science, Engineering and Technology. InTech, pp 123-148

Bilińska L, Blus K, Foszpańczyk M, et al (2020) Catalytic ozonation of textile wastewater as a polishing step after industrial scale electrocoagulation. J Environ Manage 265:110502. https://doi.org/10.1016/j.jenvman.2020.110502

Ciobanu G, Harja M (2019) Cerium-doped hydroxyapatite/collagen coatings on titanium for bone implants. Ceram Int 45:2852-2857. https://doi.org/10.1016/j.ceramint.2018.07.290

Ding Y, Huang W, Ding Z, et al (2016) Dramatically enhanced Fenton oxidation of carbamazepine with easily recyclable microscaled $\mathrm{CuFeO}_{2}$ by hydroxylamine: Kinetic and mechanism study. Sep Purif Technol 168:223-231. https://doi.org/10.1016/j.seppur.2016.05.043

Dong X, Lin Y, Ren G, et al (2021) Catalytic Degradation of Methylene Blue by Fenton-like Oxidation of Ce-doped MOF. Colloids Surfaces A Physicochem Eng Asp 608:125578. https://doi.org/10.1016/j.colsurfa.2020.125578

Duesterberg CK, Waite TD (2006) Process optimization of fenton oxidation using kinetic modeling. Environ Sci Technol 40:4189-4195. https://doi.org/10.1021/es060311v

Fida H, Zhang G, Guo S, Naeem A (2017) Heterogeneous Fenton degradation of organic dyes in batch and fixed bed using La-Fe montmorillonite as catalyst. J Colloid Interface Sci 490:859-868. https://doi.org/10.1016/j.jcis.2016.11.085

Fihri A, Len C, Varma RS, Solhy A (2017) Hydroxyapatite: A review of syntheses, structure and applications in heterogeneous catalysis. Coord Chem Rev 347:48-76. https://doi.org/10.1016/j.ccr.2017.06.009

Gonzalez-Olmos R, Holzer F, Kopinke FD, Georgi A (2011) Indications of the reactive species in a heterogeneous Fenton-like reaction using Fe-containing zeolites. Appl Catal A Gen 398:44-53. https://doi.org/10.1016/j.apcata.2011.03.005

Harja M, Ciobanu G (2018) Studies on adsorption of oxytetracycline from aqueous solutions onto hydroxyapatite. Sci Total Environ 628-629:36-43. https://doi.org/10.1016/j.scitotenv.2018.02.027

Hassan H, Hameed BH (2011) Fe-clay as effective heterogeneous Fenton catalyst for the decolorization of Reactive Blue 4. Chem Eng J 171:912-918. https://doi.org/10.1016/j.cej.2011.04.040

He X, Qi Z, Gao J, et al (2020) Nonylphenol ethoxylates biodegradation increases estrogenicity of textile wastewater in biological treatment systems. Water Res 184:116137. https://doi.org/10.1016/j.watres.2020.116137 
Ikhsan SNW, Yusof N, Ismail AF, et al (2020) Synthetic polymer-based membranes for treatment of oily wastewater. In: Synthetic Polymeric Membranes for Advanced Water Treatment, Gas Separation, and Energy Sustainability. Elsevier, pp 3-22

Jastrzębski W, Sitarz M, Rokita M, Bułat K (2011) Infrared spectroscopy of different phosphates structures. Spectrochim Acta Part A Mol Biomol Spectrosc 79:722-727. https://doi.org/10.1016/j.saa.2010.08.044

Ji F, Li C, Zhang J, Deng L (2011) Efficient decolorization of dye pollutants with $\mathrm{LiFe}(\mathrm{WO} 4) 2$ as a reusable heterogeneous Fenton-like catalyst. Desalination 269:284290. https://doi.org/10.1016/j.desal.2010.11.015

Khan S, Malik A, Akhtar R, Grohmann E (2014) Environmental Deterioration and Human Health. In: Malik A, Grohmann E, Akhtar R (eds) Environmental Deterioration and Human Health: Natural and Anthropogenic Determinants. Springer Netherlands, Dordrecht, pp 55-71

Khosroshahi AG, Mehrizad A (2019) Optimization, kinetics and thermodynamics of photocatalytic degradation of Acid Red 1 by Sm-doped CdS under visible light. J Mol Liq 275:629-637. https://doi.org/10.1016/j.molliq.2018.11.122

Kiani R, Mirzaei F, Ghanbari F, et al (2020) Real textile wastewater treatment by a sulfate radicals-Advanced Oxidation Process: Peroxydisulfate decomposition using copper oxide $(\mathrm{CuO})$ supported onto activated carbon. J Water Process Eng 38:101623. https://doi.org/10.1016/j.jwpe.2020.101623

Krukowski S, Lysenko N, Kolodziejski W (2018) Synthesis and characterization of nanocrystalline composites containing calcium hydroxyapatite and glycine. J Solid State Chem 264:59-67. https://doi.org/10.1016/j.jssc.2018.05.004

Lan Y, Barthe L, Azais A, Causserand C (2020) Feasibility of a heterogeneous Fenton membrane reactor containing a Fe-ZSM5 catalyst for pharmaceuticals degradation: Membrane fouling control and long-term stability. Sep Purif Technol 231:115920. https://doi.org/10.1016/j.seppur.2019.115920

Lellis B, Fávaro-Polonio CZ, Pamphile JA, Polonio JC (2019) Effects of textile dyes on health and the environment and bioremediation potential of living organisms. Biotechnol Res Innov 3:275-290. https://doi.org/10.1016/j.biori.2019.09.001

Long Q, Liu F, Yuan Y, et al (2020) Enhanced degradation performance of p-chlorophenol in photo-Fenton reaction activated by nano-Fe0 encapsulated in hydrothermal carbon: Improved Fe(III)/Fe(II) cycle. Colloids Surfaces A Physicochem Eng Asp 594:124650. https://doi.org/10.1016/j.colsurfa.2020.124650 
Meziani D, Abdmeziem K, Bouacida S, et al (2016) Photo-electrochemical and physical characterizations of a new single crystal POM- based material. Application to Rhodamine B photodegradation. Sol Energy Mater Sol Cells 147:46-52. https://doi.org/10.1016/j.solmat.2015.11.042

Mortadi A, Chahid EG, Elmelouky A, et al (2020) Complex electrical conductivity as a new technique to monitor the coagulation-flocculation processes in the wastewater treatment of the textile Industry. Water Resour Ind 24:100130. https://doi.org/10.1016/j.wri.2020.100130

Nishikawa H (2004) A high active type of hydroxyapatite for photocatalytic decomposition of dimethyl sulfide under UV irradiation. J Mol Catal A Chem 207:149-153. https://doi.org/10.1016/S1381-1169(03)00472-2

Oliva J, De Pablo J, Cortina J-L, et al (2011) Removal of cadmium, copper, nickel, cobalt and mercury from water by Apatite II $^{\mathrm{TM}}$ : Column experiments. J Hazard Mater 194:312323. https://doi.org/10.1016/j.jhazmat.2011.07.104

Ooi CH, Ling YP, Pung SY, Yeoh FY (2019) Mesoporous hydroxyapatite derived from surfactant-templating system for p-Cresol adsorption: Physicochemical properties, formation process and adsorption performance. Powder Technol 342:725-734. https://doi.org/10.1016/j.powtec.2018.10.043

Oulguidoum A, Bouyarmane H, Laghzizil A, et al (2019) Development of sulfonatefunctionalized hydroxyapatite nanoparticles for cadmium removal from aqueous solutions. Colloids Interface Sci Commun 30:100178. https://doi.org/10.1016/j.colcom.2019.100178

Park JH, Wang JJ, Xiao R, et al (2018) Degradation of Orange G by Fenton-like reaction with Fe-impregnated biochar catalyst. Bioresour Technol 249:368-376. https://doi.org/10.1016/j.biortech.2017.10.030

Raghav S, Sapna, Kumar D (2018) Cubical-Shaped Rods of Pectin-Hydroxyapatite Composite for Adsorption Studies of Fluoride by Statistical Method and Adsorption Experiments. ACS Omega 3:9675-9688. https://doi.org/10.1021/acsomega.8b01330

Riaz M, Zia R, Ijaz A, et al (2018) Synthesis of monophasic Ag doped hydroxyapatite and evaluation of antibacterial activity. Mater Sci Eng C 90:308-313. https://doi.org/10.1016/j.msec.2018.04.076

Roumila Y, Abdmeziem K, Meziani D, Trari M (2018) Physical and photo-electrochemical characterization of natural phosphate material. Application to basic dyes photodegradation. Res Chem Intermed 44:2621-2636. https://doi.org/10.1007/s11164- 
Roumila Y, Abdmeziem K, Rekhila G, Trari M (2016) Semiconducting properties of hydrothermally synthesized libethenite application to orange $G$ photodegradation. Mater Sci Semicond Process 41:470-479. https://doi.org/10.1016/j.mssp.2015.10.018

Saber A, Smahi A, Solhy A, et al (2003) Heterogeneous catalysis of Friedel-Crafts alkylation by the fluorapatite alone and doped with metal halides. J Mol Catal A Chem 202:229237. https://doi.org/10.1016/S1381-1169(03)00186-9

Sangeetha K, Ashok M, Girija EK, et al (2018) Strontium and ciprofloxacin modified hydroxyapatites as functional grafts for bone prostheses. Ceram Int 44:13782-13789. https://doi.org/10.1016/j.ceramint.2018.04.221

Santana CS, Nicodemos Ramos MD, Vieira Velloso CC, Aguiar A (2019) Kinetic Evaluation of Dye Decolorization by Fenton Processes in the Presence of 3-Hydroxyanthranilic Acid. Int J Environ Res Public Health 16:1602. https://doi.org/10.3390/ijerph16091602

Sebatini S, Kalluri S, Anish Madhavan A (2020) Green synthesized $\alpha-\mathrm{Fe}_{2} \mathrm{O}_{3}$ mesoporous network for heterogeneous Fenton oxidation of thiazine dye. Mater Lett X 5:100037. https://doi.org/10.1016/j.mlblux.2019.100037

Sebti S, Solhy A, Tahir R, Smahi A (2002) Modified hydroxyapatite with sodium nitrate: An efficient new solid catalyst for the Claisen-Schmidt condensation. Appl Catal A Gen 235:273-281. https://doi.org/10.1016/S0926-860X(02)00273-9

Sun B, Li H, Li X, et al (2018) Degradation of Organic Dyes over Fenton-Like $\mathrm{Cu}_{2} \mathrm{O}-\mathrm{Cu} / \mathrm{C}$ Catalysts. Ind Eng Chem Res 57:14011-14021. https://doi.org/10.1021/acs.iecr.8b02697

Suraj P, Kumar V, Thakur C, Ghosh P (2019) Taguchi optimization of COD removal by heterogeneous Fenton process using copper ferro spinel catalyst in a fixed bed reactor RTD, kinetic and thermodynamic study. J Environ Chem Eng 7:102859. https://doi.org/10.1016/j.jece.2018.102859

Tang X, Li Z, Liu K, et al (2020) Sulfidation modified $\mathrm{Fe}_{3} \mathrm{O}_{4}$ nanoparticles as an efficient Fenton-like catalyst for azo dyes degradation at wide $\mathrm{pH}$ range. Powder Technol 376:42-51. https://doi.org/10.1016/j.powtec.2020.08.018

Vahdat A, Ghasemi B, Yousefpour M (2019) Synthesis of hydroxyapatite and hydroxyapatite/ $\mathrm{Fe}_{3} \mathrm{O}_{4}$ nanocomposite for removal of heavy metals. Environ Nanotechnology, Monit Manag 12:100233. https://doi.org/10.1016/j.enmm.2019.100233 Venkateswarlu K, Chandra Bose A, Rameshbabu N (2010) X-ray peak broadening studies of nanocrystalline hydroxyapatite by Williamson-Hall analysis. Phys B Condens Matter 405:4256-4261. https://doi.org/10.1016/j.physb.2010.07.020 
Wan W, Zhang Y, Ji R, et al (2017) Metal Foam-Based Fenton-Like Process by Aeration. ACS Omega 2:6104-6111. https://doi.org/10.1021/acsomega.7b00977

Wang J, Gong X, Hai J, Li T (2018) Synthesis of silver-hydroxyapatite composite with improved antibacterial properties. Vacuum 152:132-137. https://doi.org/10.1016/j.vacuum.2018.03.015

Wang N, Zheng T, Zhang G, Wang P (2016) A review on Fenton-like processes for organic wastewater treatment. J Environ Chem Eng 4:762-787. https://doi.org/10.1016/j.jece.2015.12.016

Wang Q, Tian S, Ning P (2014) Degradation Mechanism of Methylene Blue in a Heterogeneous Fenton-like Reaction Catalyzed by Ferrocene. Ind Eng Chem Res 53:643-649. https://doi.org/10.1021/ie403402q

Wu J, Doan H, Upreti S (2008) Decolorization of aqueous textile reactive dye by ozone. Chem Eng J 142:156-160. https://doi.org/10.1016/j.cej.2007.11.019

Xue X, Hanna K, Abdelmoula M, Deng N (2009) Adsorption and oxidation of PCP on the surface of magnetite: Kinetic experiments and spectroscopic investigations. Appl Catal B Environ 89:432-440. https://doi.org/10.1016/j.apcatb.2008.12.024

Yang Y, Wu Q, Wang M, et al (2014) Hydrothermal Synthesis of Hydroxyapatite with Different Morphologies: Influence of Supersaturation of the Reaction System. Cryst Growth Des 14:4864-4871. https://doi.org/10.1021/cg501063j

Zahouily M, Abrouki Y, Bahlaouan B, et al (2003) Hydroxyapatite: new efficient catalyst for the Michael addition. Catal Commun 4:521-524. https://doi.org/10.1016/j.catcom.2003.08.001

Zárate-Guzmán AI, González-Gutiérrez L V., Ocampo-Pérez R, et al (2020) Iron precursor salt effect on the generation of $\mathrm{OH}$ radicals and sulfamethoxazole degradation through a heterogeneous Fenton process using Carbon-Fe catalysts. J Water Process Eng 36:101273. https://doi.org/10.1016/j.jwpe.2020.101273

Zaviska F, Drogui P, Mercier G, Blais J-F (2009) Procédés d'oxydation avancée dans le traitement des eaux et des effluents industriels: Application à la dégradation des polluants réfractaires. Rev des Sci l'eau 22:535-564. https://doi.org/10.7202/038330ar

Zhang Q, Wang Q, Wang S (2020) Efficient heterogeneous Fenton-like catalysis of Fe-doped SAPO-44 zeolite synthesized from bauxite and rice husk. Chem Phys Lett 753:137598. https://doi.org/10.1016/j.cplett.2020.137598

Zhang X, Ding Y, Tang H, et al (2014) Degradation of bisphenol A by hydrogen peroxide activated with $\mathrm{CuFeO}_{2}$ microparticles as a heterogeneous Fenton-like catalyst: 
Efficiency, stability and mechanism. Chem Eng J 236:251-262. https://doi.org/10.1016/j.cej.2013.09.051

Zhou Y, Zhang Y, Li Z, et al (2020) Oxygen reduction reaction electrocatalysis inducing $584 \quad$ Fenton-like processes with enhanced electrocatalytic performance based on mesoporous $\mathrm{ZnO} / \mathrm{CuO}$ cathodes: Treatment of organic wastewater and catalytic principle.

$586 \quad$ Chemosphere 259:127463. https://doi.org/10.1016/j.chemosphere.2020.127463

587 Zubir NA, Yacou C, Zhang X, Diniz da Costa JC (2014) Optimisation of graphene oxideiron oxide nanocomposite in heterogeneous Fenton-like oxidation of Acid Orange 7. J Environ Chem Eng 2:1881-1888. https://doi.org/10.1016/j.jece.2014.08.001 


\section{Figures}
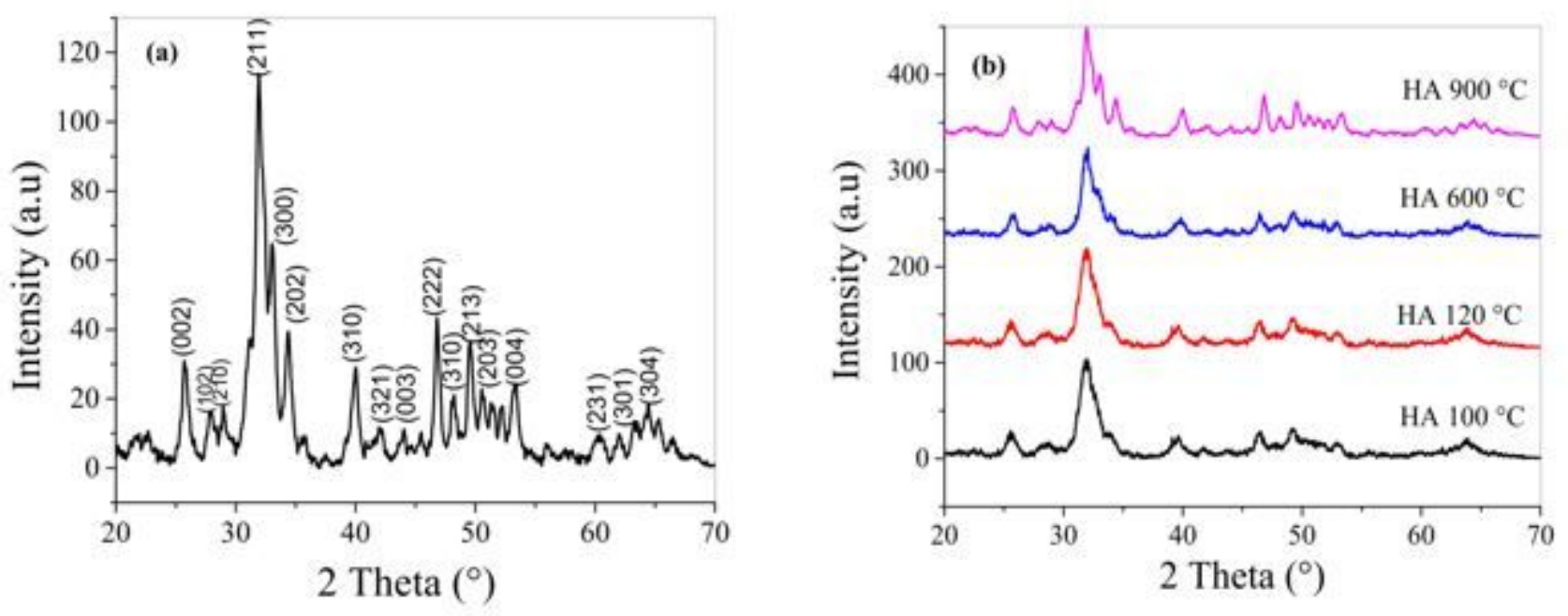

\section{Figure 1}

Diffractogram of: (a) synthesized hydroxyapatite; (b) hydroxyapatite at different calcination temperatures

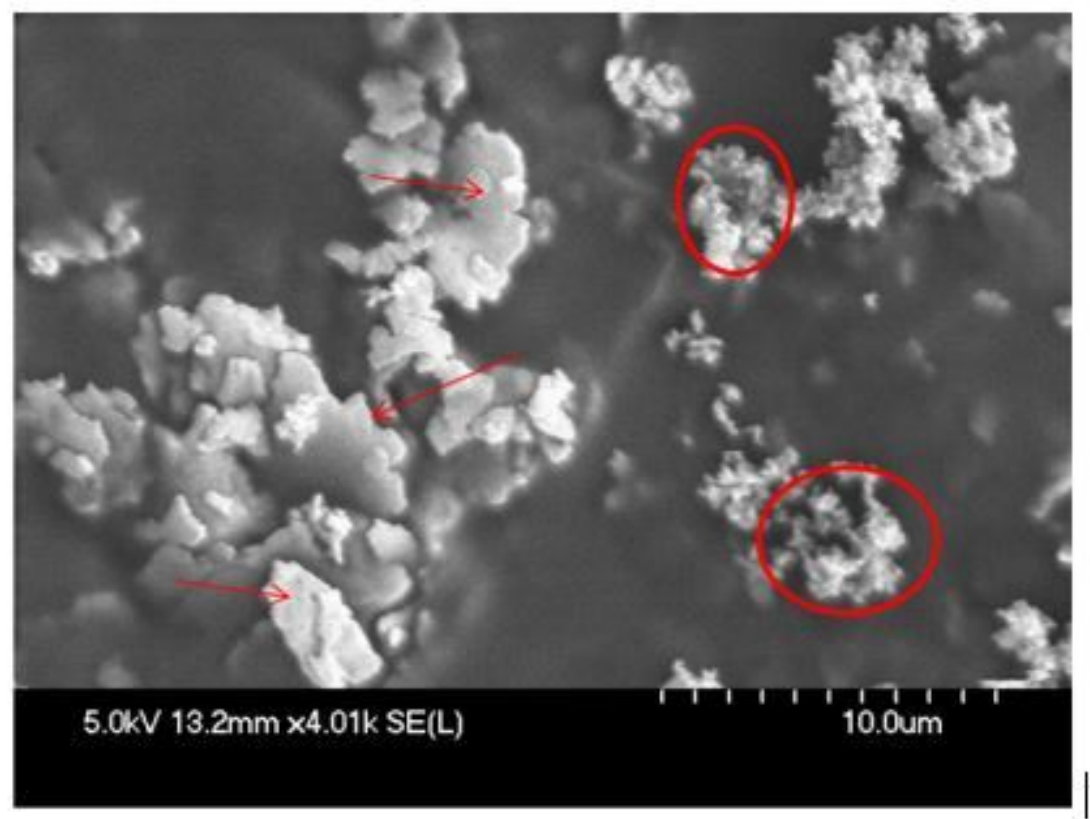

Figure 2

SEM image of synthesized HA 


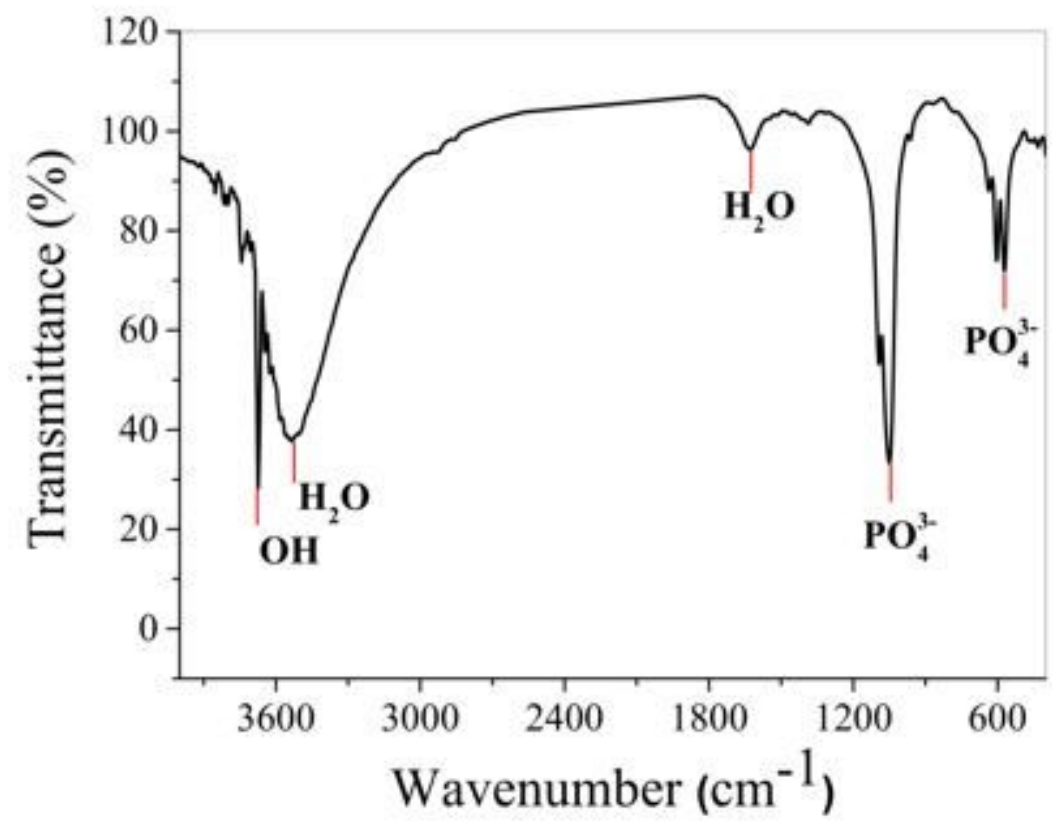

Figure 3

FTIR spectrum of $\mathrm{Ca} 5(\mathrm{PO} 4) 30 \mathrm{H}$
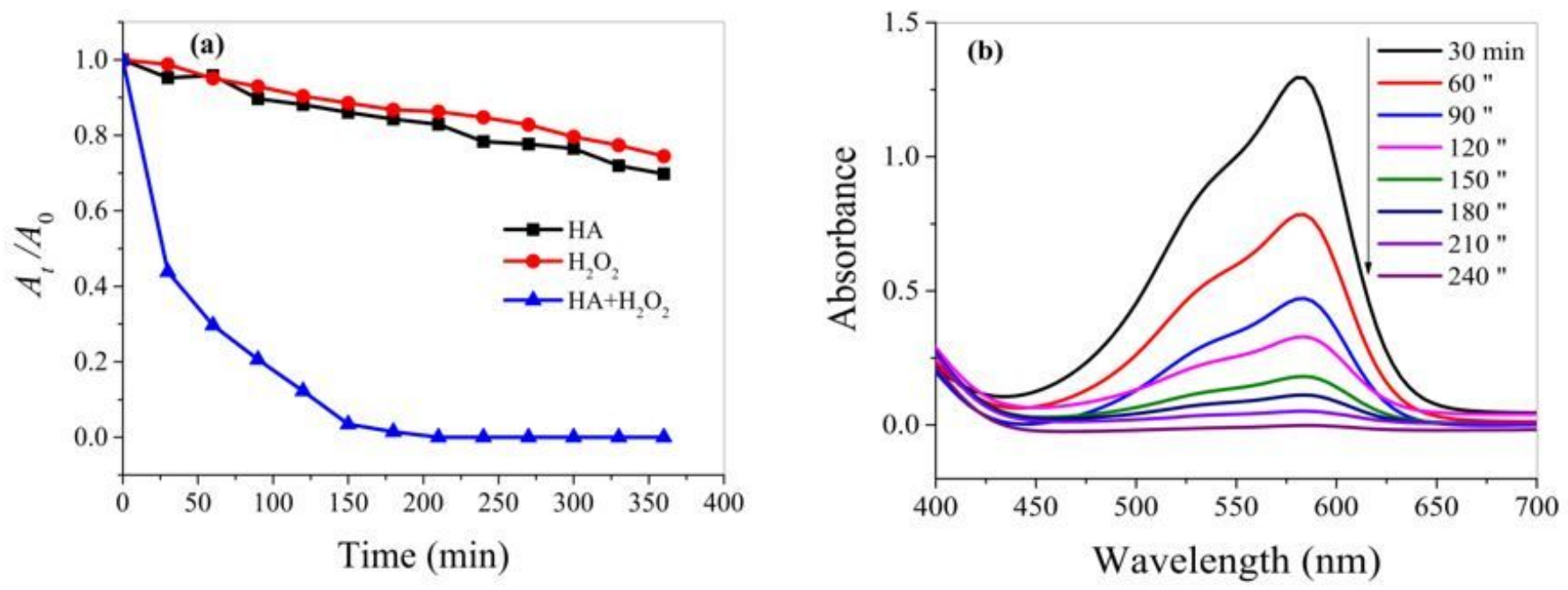

Figure 4

(a) Comparison of the degradation efficiency of MV at $20 \mathrm{mg} \mathrm{L}-1$ under various systems; (b) Absorption spectra of MV according to the Fenton-like process $\left(T=19 \pm 2{ }^{\circ} \mathrm{C}, \mathrm{pH}=6.65\right.$, [MV] $=20 \mathrm{mg} \mathrm{L}-1, \mathrm{HA}$ dose $=$ $2.5 \mathrm{~g} \mathrm{~L}-1$ and [H2O2] $=12 \mathrm{mmol} \mathrm{L-1)}$ 


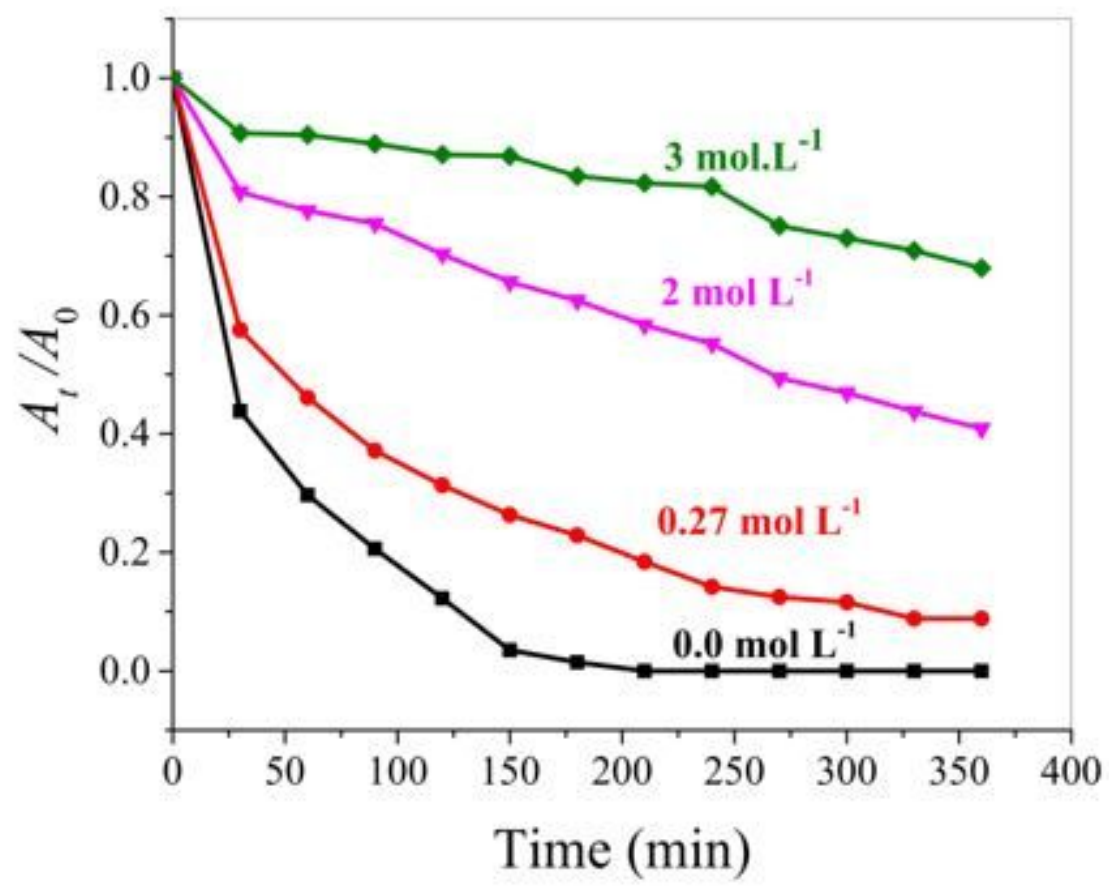

Figure 5

Degradation of $\mathrm{MV}$ in the presence of TBT at different concentrations $\left(\mathrm{T}=19 \pm 2{ }^{\circ} \mathrm{C}, \mathrm{pH}=6.65,[\mathrm{MV}]=20\right.$ $\mathrm{mg} \mathrm{L}-1, \mathrm{HA}$ dose $=2.5 \mathrm{~g} \mathrm{~L}-1$, [H2O2] $=12 \mathrm{mmol} \mathrm{L-1})$

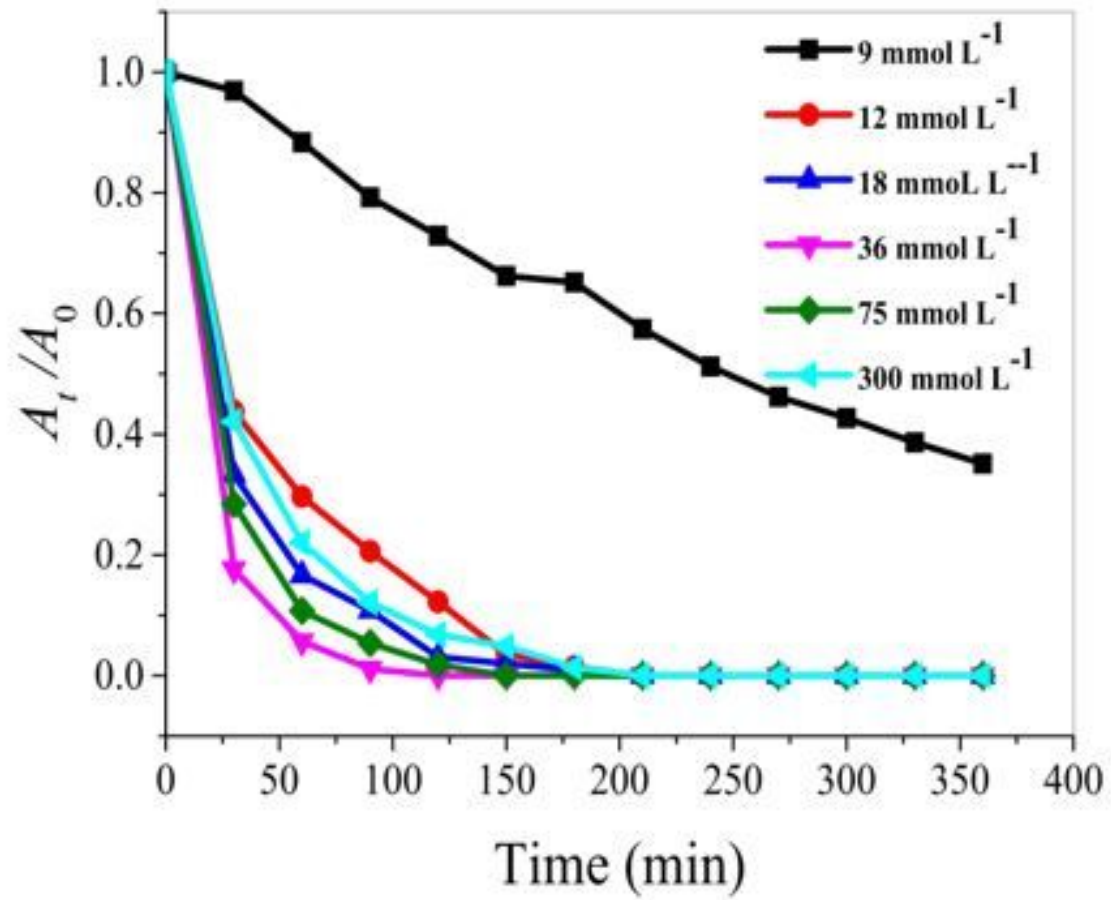

Figure 6

Effect of $\mathrm{H} 2 \mathrm{O} 2$ concentration on MV dye degradation. $\left(\mathrm{T}=19 \pm 2{ }^{\circ} \mathrm{C}, \mathrm{pH}=6.65\right.$, [MV] $=20 \mathrm{mg} \mathrm{L}-1, \mathrm{HA}$ dose $=2.5 \mathrm{~g} \mathrm{~L}-1)$. 


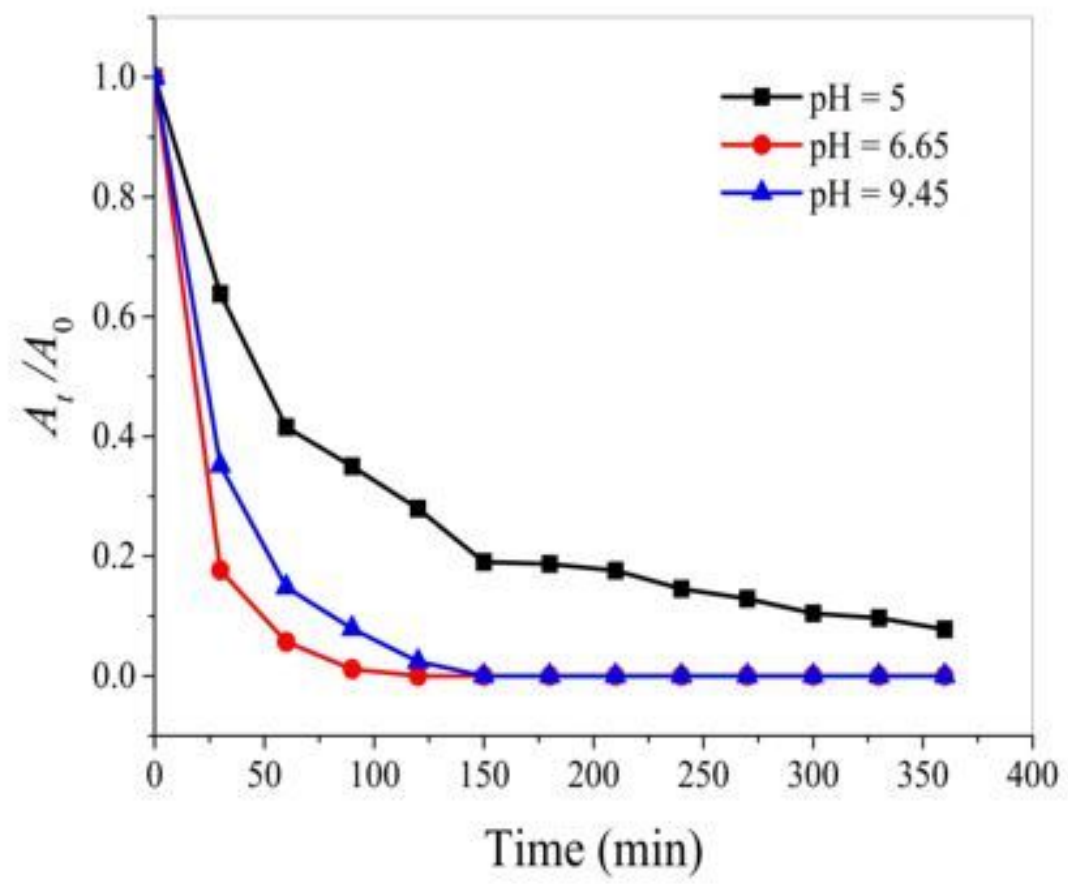

Figure 7

Effect of initial pH on MV degradation $\left(T=19 \pm 2{ }^{\circ} \mathrm{C},[\mathrm{MV}]=20 \mathrm{mg} \mathrm{L}-1,[\mathrm{H} 2 \mathrm{O} 2]=36 \mathrm{mmol} \mathrm{L}-1, \mathrm{HA}\right.$ dose $=$ $2.5 \mathrm{~g} \mathrm{~L}-1)$

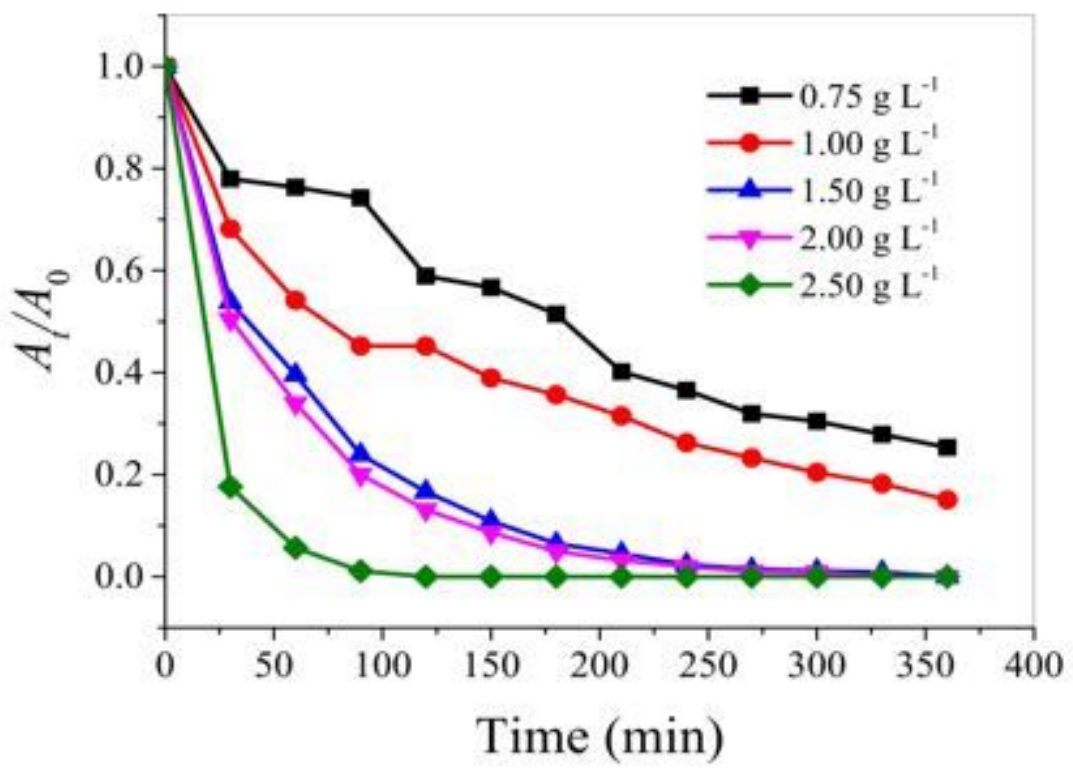

\section{Figure 8}

Effect of the catalyst dose on the degradation efficiency of $\mathrm{MV}\left(\mathrm{T}=19 \pm 2{ }^{\circ} \mathrm{C}, \mathrm{pH}=6.65,[\mathrm{MV}]=20 \mathrm{mg} \mathrm{L}-1\right.$ and $[\mathrm{H} 2 \mathrm{O} 2]=36 \mathrm{mmol} \mathrm{L}-1)$ 


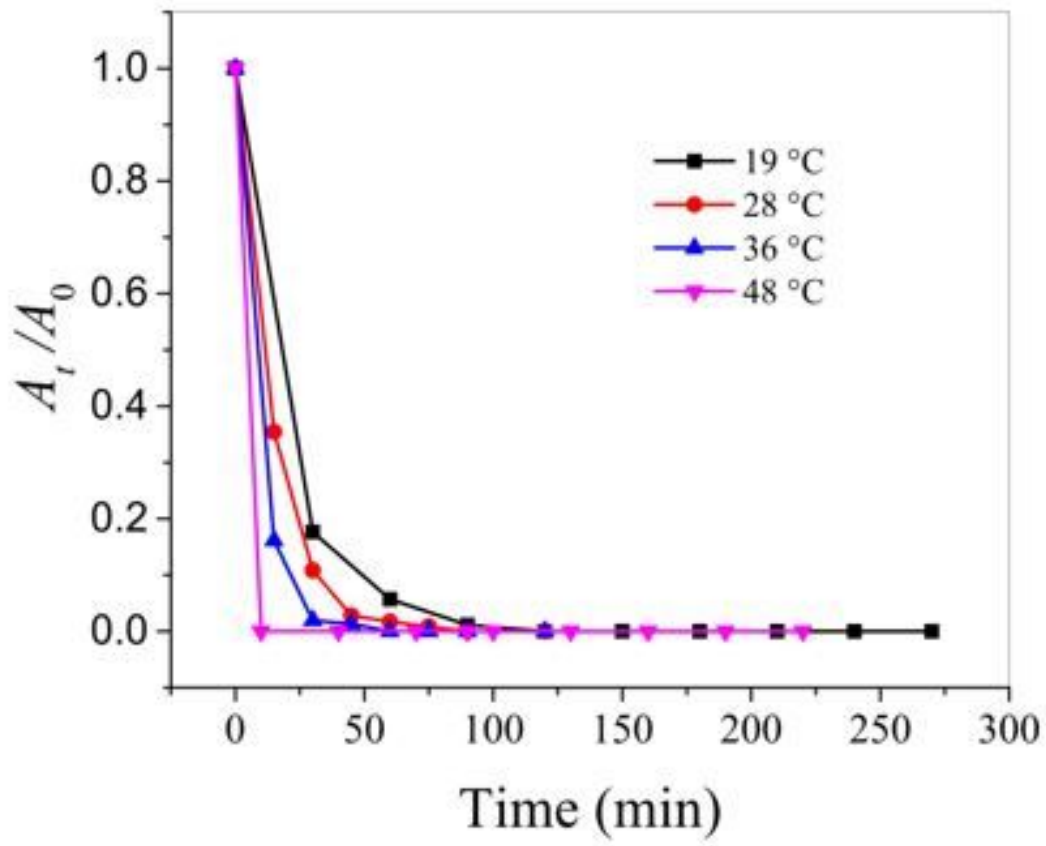

Figure 9

Effect of temperature on MV degradation $(\mathrm{pH}=6.65,[\mathrm{MV}]=20 \mathrm{mg} \mathrm{L}-1,[\mathrm{H} 2 \mathrm{O} 2]=36 \mathrm{mmol} \mathrm{L-1}, \mathrm{HA}$ dose $=$ $2.5 \mathrm{~g} \mathrm{~L}-1)$

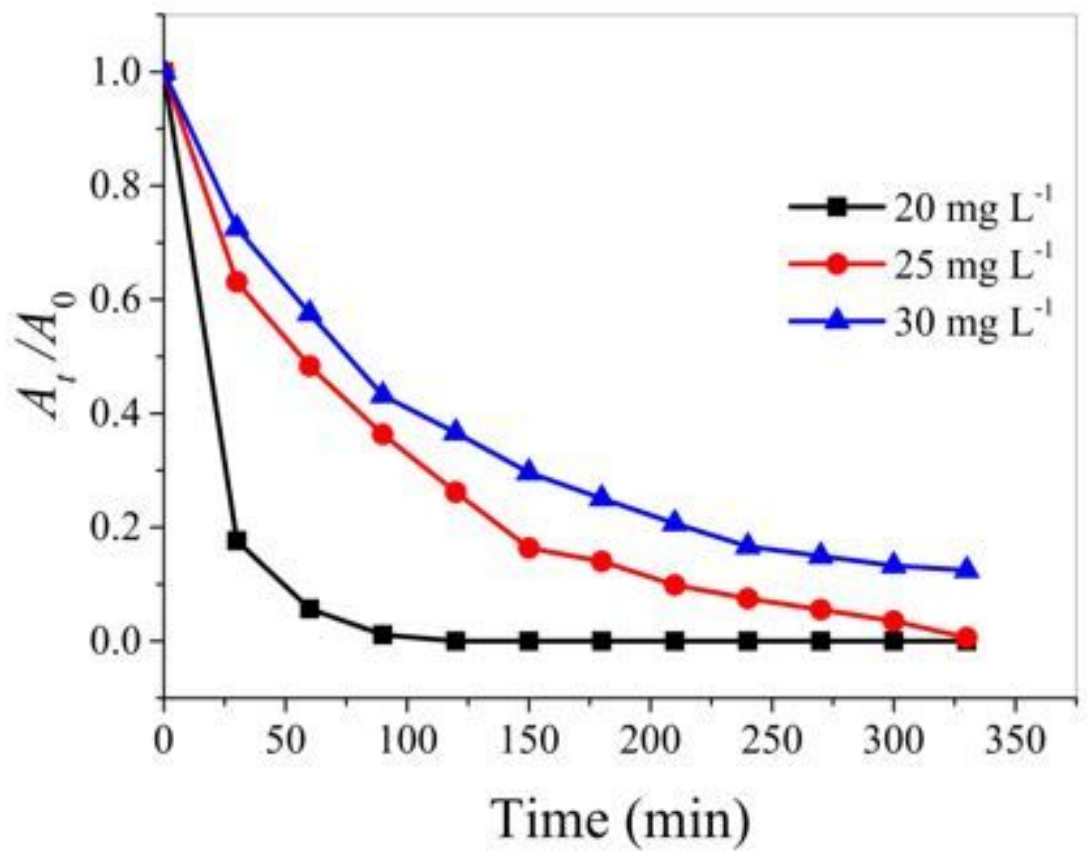

Figure 10

Effect of the initial concentration of MV solutions $\left(\mathrm{T}=19 \pm 2{ }^{\circ} \mathrm{C}, \mathrm{pH}=6.65,[\mathrm{H} 2 \mathrm{O} 2]=36 \mathrm{mmol} \mathrm{L}-1\right.$ and $\mathrm{HA}$ dose $=2.5 \mathrm{~g} \mathrm{~L}-1$ ) 


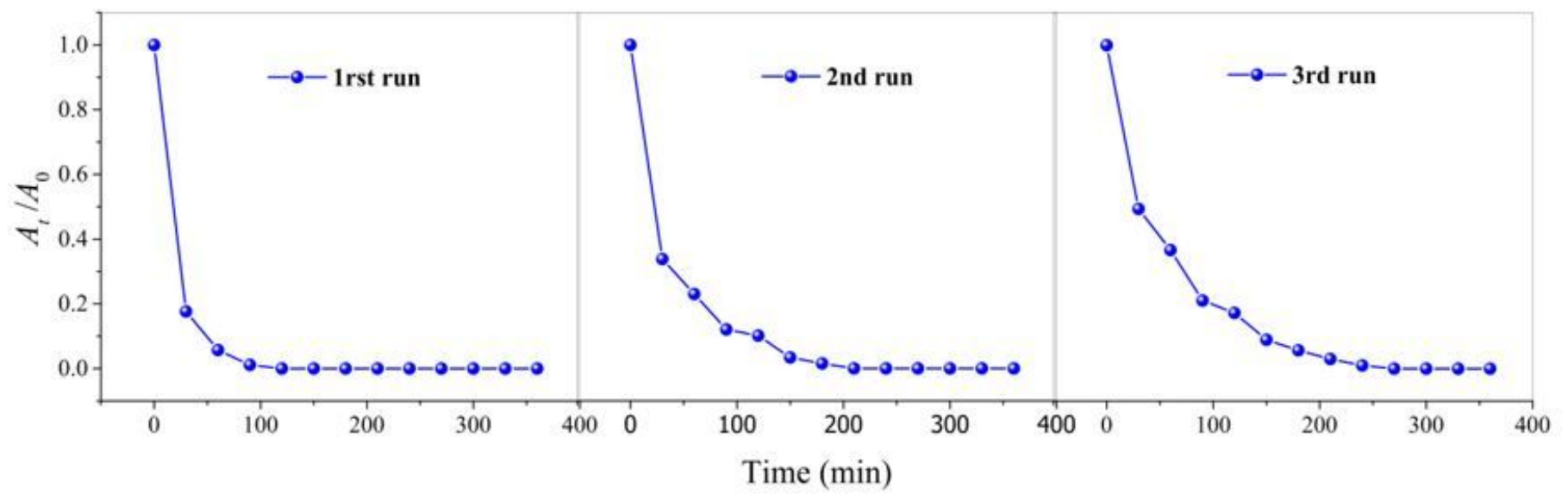

Figure 11

Catalyst recycling in MV degradation via a Fenton like process $\left(\mathrm{T}=19 \pm 2{ }^{\circ} \mathrm{C}, \mathrm{pH}=6.65,[\mathrm{MV}]=20 \mathrm{mg} \mathrm{L}-1\right.$, [H2O2] $=36 \mathrm{mmol} \mathrm{L}-1$ and $\mathrm{HA}$ dose $=2.5 \mathrm{~g} \mathrm{~L}-1$ )

\section{Supplementary Files}

This is a list of supplementary files associated with this preprint. Click to download.

- Supplementarymaterial.docx 